\title{
DE VENECIA A FAMAGUSTA (VIAJE DE 'ELIYAHU DA PESARO - 1563)
}

\author{
POR \\ José Ramón Magdalena Nom de DÉU \\ Y \\ JOSEPH SHATZMILLER
}

\section{RESUMEN}

El texto que aquí ofrecemos es la primera traducción completa -y anotada-a una lengua occidental de un único manuscrito hebreo (n. 274 en cuarto, ancien fond n. 124, folios 112-123 v. de la Bibliothèque Nationale de Paris) conteniendo la relación del viaje por el Mediterráneo, desde Venecia a Famagusta, del judío italiano Eliyahu da Pesaro en 1563.

El contenido puede dividirse en cuatro grandes apartados del mayor interés: 1) Las recomendaciones, avisos y sugerencias del viajero en todo lo referente a los trámites y gestiones previas a la contratación de pasaje y embarque en las galeras, así como el ambiente y agitación reinates en Venecia en los días anteriores a la partida. 2) Una minuciosa y muy detallada descripción de la galera. 3) La singladura por el Adriático y Egeo, hasta Famagusta y 4) Descripción de la isla de Chipre, de sus habitantes - tanto los cristianos ortodoxos como los judíos- y sus usos y costumbres.

\section{ABstract}

From Venice to Famagusta: 'Eliyahu da Pesaro's travel

This paper offers the very accurate and interesting description of a journey through the Mediterranean, from Venice to Famagusta, of an italian Jew, Eljyahu da Pesaro, in 1563, based on the hebrew text of the unique ms. extant at the Bibliothèque Nationale de Paris. The four main topics of the text are: 1) the 
ambiance and general situation of the venetian port during the previous days of the departure of the galleon. 2) the conditions of the voyage on the boat itself 3) the Eliyahu's itinerary trhough the Adriatic and Egean seas and 4) the island of Cyprus, specially the city of Famagusta and the living conditions there.

\section{INTRODUCCIÓN}

De este viajero sabemos tan sólo cuanto él mismo nos ha dejado por escrito en su relato de viaje ${ }^{1}$. Era un rico judío originario de la ciudad de Pésaro (Italia) que emigró a 'Ereș-Yisra'el con su familia ${ }^{2}$ para cumplir un voto ${ }^{3}$. El día 4 de agosto de $1563^{4}$ emprende viaje desde Venecia a bordo de una galera y recorrió el siguiente trayecto: Pola $^{5}$, Corfú ${ }^{6}, Z^{2}{ }^{7}{ }^{7}$ y, el 11 de septiembre del mismo año ${ }^{8}$ arribó a Famagusta, ciudad portuaria del este de la isla de Chipre.

En la galera había otros judíos: un italiano ${ }^{9}$, un rabino aškenazít ${ }^{10}$, tres orientales $^{11}$ y un anciano sefardí de Pésaro ${ }^{12}$, quienes continuaron viaje hasta Trípoli. Pero 'Eliyahu y los suyos, así como otro judío italiano ${ }^{13}$, se quedaron

1 El único ms. hebreo que nos ha llegado se custodia en la Bibliothèque Nationale de Paris ( $\mathrm{n}^{\circ}$ 276 , en $4^{\circ}$, ancien fond $n^{\circ} 124$, fotios $112-123 \mathrm{v}^{\circ}$ ). Fue parcialmente traducido al alemán por J. M. JOST: Schreiben des Elioh von Pesaro aus Famagusta auf Cypern vom J. 1563, 18. October...,"JAHRBUCH FÜR DIE GESCHICHTE DER JUDEN UND DES JUDENTHUMS" (Leipzig) II (1861), pp. S-38. El texto hebreo fue publicado por BEER GoldBerg en la revista "HAYYE-'OlaM" (Wien) I (1878), pp. 7-25; tambićn LUNZ en "HA-ME'AMER" (Jerusalem) II], pp. 231-268 y EISENSTEIN en su 'Osar ha-Masa'ot...(New York 1926), pp. 166-172. Nuestra versión sigue el texto depurado de YA'ARY, 'ABRAHAM: Mas. 'ot'Eress-Yisra'el..., Ramat-Gan 1976, pp. 166-196, si bien hemos tenido a ia vista una excelente reproducción fotográfica del ms. Hay una versión francesa del texto íntegro de Goldberg a cargo de SCHWAB, MOÏSE: Voyage ethnographique de Venise à Chypre. Lettre d'Élie de Pesaro datée de Famagouste. 18 octobre 1563. "Revue De GÉOGRAPHIE" (Paris) V (1879), pp. 206-228.

2 Hace referencias a los suyos en repetidas ocasiones. Vide la nota siguiente.

3 Tal como él mismo apunta: "...acaso decidiría dejar aquí parte de mis familiares y en esa ocasión, para el año que viene, subiría a lo alto del Monte de los Oljvos para cumplir mi voto..."

4 El día 15 de 'Ab de 5.323 (4 de agosto de 1.563 ).

5 Sale de Pola el 25 de 'Ab de 5.323 (14 de agosto de 1.543).

- Sale de Corfú el 4 de 'Elul de 5.323 (23 de agosto de 1.563).

7 Llega a Zante el 7 de 'Elui de 5.323 (26 de agosto de 1.563) y sale de allí el 12 de 'Elul de 5.323 (31 de agosto de 1.563 ).

8 El sábado anterior al primero del año judío de 5.324, a las cinco semanas de navegación y escalas ( 23 de 'Elul de 5.323 ).

9 Šelomoh da Pisa.

1v Iba a Jerusalén con su familia.

11 Son judíos levantinos que iban a Safed.

12 No consta el nombre.

33 R. Yișhaq Pulieso, que residía en Ferrara.

Imagen y representación de los otros

Hispania Sacra 48 (1996) 
temporalmente en Famagusta al llegarles la noticia de que en Siria, Líbano y Jerusalén se había declarado un importante brote de peste ${ }^{14}$ y temían proseguir su camino. Nuestro viajero explica que considera más prudente esperar en Chipre que en Trípoli, ya que es más fácil llegar a 'Ereș-Yisra'el desde la isla, por vía marítima, que a travếs de Siria, por vía continental ${ }^{15}$.

En su larga epístola, escrita el primer día del mes de Ḥ ešwán del año $5324^{16}$, a las cinco semanas de su llegada a Chipre, describe a su hermanodestinatario de la carta- con sumo detalle las características de la galeaza veneciana ${ }^{17}$ en la cual viajó, le anima a emigrar a Tierra Santa y le da buenos y útiles consejos: cómo comportarse en Venecia a la hora de contratar y elegir el lugar en la nave así como todos los preparativos para la travesía y cómo comportarse a bordo ${ }^{18}$. Describe después las localidades por donde pasó, la población judía de Corfú y el trato que los griegos dispensan a los judíos; su llegada a Chipre y las razones que le han decidido a detenerse momentáneamente en Famagusta. Finalmente, describe con todo lujo de detalles la isla, su religión dominante (la ortodoxa griega), el clima y las costumbres de sus lugareños, las vituallas y sus precios, los judíos que allí residen y el negocio del préstamo dinerario que sus correligionarios realizan entre los gentiles, obteniendo pinguies beneficios ${ }^{19}$.

En Chipre se encontró nuestro viajero con 25 familias de judíos (orientales, sicilianos y sefardíes) y al gran rabino 'Elie 'ézer 'Ałkkenazi ${ }^{20}$.

Al final de su carta vuelve a animar a su hermano para que emigre a 'EreșYisra'e ${ }^{21}$.

14 "...todos los países de Siria están afectados por una plaga y una peste..."

is Con todo, advierte que Famagusta "...está cercana para ir a mi destino, más que Trípoli y que Rodas, pues se asienta en el ombligo del mundo..." desde donde "...zarpan galeras para ir allí y allá...", si bien "...los judíos se guardan de ir durante el verano a Yafo y también a Acre, porque temen a las galeras maltesas... pero al entrar en el mes de octubre, hasta todo el mes de marzo, no hny temor y se va seguro..." Hace alusión a los corsarios de Malta, último reducto de los caballeros de la Orden del Hospital de San Juan de Jerusalén.

th Es el 18 de octubre de 1.563 .

17 Da las dimensiones de ta nave, su arboladura y velamen, armamento, remos, la distribución de los compartimientos y dependencias, tripulación y mando, etc.

I8 Es de gran interés la minuciosa descripción que hace de los complicados trámites burocráticos que todo viajero debía realizar para conseguir una plaza a bordo de las galeras venecianas.

19 Él mismo invirtió su capital a un plazo de diez días, mediante prendas hipotecarias de oro y plata, a réditos que oscilaban entre el $30 \%$ y el $50 \%$.

2i Había ejercido como juez de las comunidades de Egipto durante 22 años, pero debió salir de aquel país, con su familia, "por causa accidental". Hacía dos años que estaba en Famagusta. Era hombre jlustrado -dominaba doce lenguas, era experto en Talmud y Halakah y sabio en ciencias profanas- y muy rico. 
'Eliyahu era hombre entendido en los negocios y asuntos mundanos, poseedor de buenas dotes de observador y polifacéticos intereses ${ }^{22}$. En su epístola se contienen abundantes y precisos datos sobre el tipo de viajes que, desde el puer-to de Venecia, emprendían los comerciantes, peregrinos y emigrantes italianos hacia oriente y 'Ereş-Yisra' $\mathrm{el}^{23}$.

21 Así, le escribe con gran lirismo: "¿cuándo vendrá (el momento) que podré ver vuestros rostros excelsos en la Tierra Santa?".

22 Adernís de una sólida formación en estudios rabínicos, 'Eliyahu muestra interés por las cuestiones médicas y de salubridad. Ya hemos dicho que se detuvo en Chipre debido a la peste que azotaba Siria y también describe con precisión la enfermedad ocular que afectaba a la población local. Posiblemente era rabino y médico, aunque esta afirmación no consta de manera explícita en el texto que nos ha llegado. Vide el interesante trabajo de OLIVIERI, ACHILLE: $/ /$ medico ebreo nella Venezia del Quattrocento e Cinquecento.- "GL, EBREI E VENEZIA. SECOLI XIV-XVIII" Venezia [983, pp. 449-468.

23 Vide el interesante libro de SOTTAS, JULES: Les Messageries Maritimes de Venise aux XIV et $X V^{c}$ siècles. Paris 1938, donde se pasa revista a la expansión de Venecia por el Mediterráneo, el comercio, la construcción de barcos, armamentos, líneas comerciales, viajeros, travesías, etc. Astmismo los artículos de TUCCI, UGO: Sur la pratique yénitienne de la navigation au XVI' sièclé. Quelques remarques.- "ANNALES" (Paris) XIII (1958), pp. 72-82 y TENENTI, ALBERTO - VIVANTI, CORRADO: Le film d'un grand système de navigation: Les galères marchandes vénitiennes. XIV"XVT siècles.- "ANNALES" (Paris) XIII (1958), pp. 83-86.

lmagen y representación de los otros Hispania Sacra 48 (1996) 
VIAJE DE 'ELIYAHU DA PESARO (1563)

\section{TRADUCCIÓN}

Tú, mi camarada y mi amigo, que deseas saber todos los detalles que necesita un hombre cuyo corazón se ha ofrecido a ir a esas comarcas con las galeazas venecianas $^{24}$, es necesario que sepas que las galeazas enviadas por la alta autoridad desde Venecia, sea a Beirut ${ }^{25}$, sea a Trípoli, sea a Alejandría, son todas iguales, tanto una como otra, y están distribuidas según un orden, sin diferencia alguna entre ellas. Son de 70 codos de longitud y 18 codos de anchura, según la medida media de Italia. Cada una de ellas está provista de piezas de artillería de grueso calibre, además de los mosquetes y falconetes, arcabuces de posta, troncos y vasijas llenas de fuego artificial como no hay medida.

En cada galera encontrarás tres palos: mayor, mediano y menor. El palo mayor está en medio, sobre el que penden la vela mayor, llamada artimone ${ }^{26}$, es de ocho piezas, tiene en sí 2.500 codos de trapo y, a veces, debido a la confusión de las estaciones y al cambio de los tiempos, la retiran para poner otra en su lugar, llamada tercerola: tiene 1.700 codos de trapo. Cuando el mar se embravece mucho ponen otra en su lugar, más pequeña, llamada pappafico, que tiene 1.200 codos de trapo, llamada la gabbia, y no hacen uso de ella más que cuando están en gran peligro, hasta que casi se ha perdido la esperanza y ya han desconfiado de la salvación...

24 Vide SOTTAS, JULES; Les Messageries maritimes de Venise aux XIVe \& XVe siècles. Paris 1938, especiolmente el cap. IV Les bâtiments (pp. 52-83) y cap. V Les armements (pp. 84-102) y CASAS HOMS, J. M.: Reparació d'una galera l'any 1390.- "MiscelanEA de teXtos MEDievales" (Barcelona) II (1974), pp. 167-217.

25. El ms. dice, sin duda "PY'NDRH", pero YA 'ARY propone "Beirut". SCHWAB -que pudo consultar el ms.- ofrece el extraño "Frandera" y en nota explica que "n'est peut-être qu'une corruption du nom de Brindisi".

26. Algunas voces italoaljamiadas van en cursiva. 
En el palo mediano, que está cerca de la popa, ponen otra vela llamada mesana, que tiene 1.300 codos de trapo. Y en el palo tercero, que está en proa, hay otra vela pequeña llamada trinquete, que tiene 300 codos de trapo.

Nunca se da el caso de que la autoridad resuelva enviar una sola galera a ningún lugar, sino dos o tres juntas. El jefe encargado de ellas tiene orden y aviso de no arriar las velas, pues ello es señal de rendición y perdición; igualmente, si vinieran sobre ellos muchas galeras y piratas a cobrar botín y tomar saqueo, fueren del país que fueren y de cualquier príncipe o señor, ya togarmín ${ }^{27}$, ya cristiano, si no fuese una armada que sobrepase un total de cien velas la que viniere contra ellos. Y quien desobedeciere el mandato antedicho deberá su cabeza a la república.

Aunque la costumbre es que mientras las galeras del togarmí pidan verlos en paz, les envían presentes, a veces 1.000 y a veces 2.000 , todo según la cantidad de galeras que encuentren, y después todos se dirigen a sus rumbos; ése hacia poniente y ése hacia septentrion, y tales dineros son pagados por los comerciantes que tienen bienes en la galera, y se evalúa a tenor del cálculo del dinero que se encuentra escrito en el libro.

En la galera capitana va siempre allí uno de los grandes de Venecia llamado $\mathrm{El}$ Capitán, y en la otra -o las otras- (uno) llamado Conserva. En la capitana encuentras un gran mascarón de oro en la popa, que llą̣man polena, pues en él se fijará la que va detrás, y el jefe que está en ella comanda también a las otras. A su mandato fondearán y zarparán, tiene facultad para juzgar en casos civiles y criminales, y tiene guardianes que castigan a las gentes poniéndoles cadenas, y también aplican tormento para matar a los malvados ${ }^{28}$, y todos los hombres que van dentro de las galeras se doblegan a su disciplina, desde el inferior al superior, y las galeras de acompañamiento no mudarán parecer tras sus palabras. Por ello deben ir siempre tras la capitana, como siguiéndola, para estar con ella, ya en navegación, ya estando paradas, tras ella y no ante ella, y no a más de una milla lejos de ella.

Acostumbra la autoridad vender el alquiler de las galeras a distintas personas, ciudadanos y nobles de Venecia, a ése una y a aquél otra, y dan un tanto fiado y ellos se contratan, y cada uno es patrón de ella y la pone en alquiler, tanto a la ida como a la vuelta, y de su propio peculio pagan los jornales de los artífices y los galeotes que van a bordo.

Tienen un libro de registro fidedigno y un escribano fidedigno para registrar la mercadería y los hombres y los caudales que vienen a él. Asimismo la autoridad elige el envío a bordo de la capitana de doce hombres sabios y versados en las estaciones y expertos en el oficio de la navegación, y cuando se diere vicisitud (alguna) o cambio sustancial en el tiempo, se reúnen juntos en un lugar y toman consejo entre ellos para

27 Turco, es decir, musulmán.

28 El patrón de una galera veneciana castigó a un remero cristiano por haber insultado a $\mathbf{M}$ šul.Jam da Volterra (1487). En la mișma nave viajaba R. 'Obadyah da Bertinoro, qujen da cuenta del incidente. Vide MAGDALENA NOM DE DÉu, José RAMON: Relatos de viajes y epístolas de peregrinos judios a Jeru.salén. Sabadell 1987, pp. 107-108. 
decidir qué hacer. Se llama "el Consejo de los Doce"; el acuerdo que ellos toman así se llevará inmediatamente a la práctica, sin demora.

Hay siempre tres guardias en cada galera, una en lo alto del palo, una en la popa y una en la proa, y están de puesto durante tres horas; después se cambian y se turnan siempre, tanto de noche como de día, y observan el mar a una distancia de 50 millas por cada lado.

En cada galera hallarás, por cierto, dos médicos: uno físico y otro cirujano; y especiero, peluquero, amanuense, cura, sastre, carpintero, herrero, talabartero, carnicero, gañán para dar de comer al ganado; asimismo hallarás para comprar toda clase de mercaderías que quieras, y podrás comprar vino, aceite, huevos, pescado salado, carne salada, frutas, verduras, comida que viene en bolsitas y toda clase de entremeses ${ }^{29}$. También están el camarero y ej panadero. Hay asimismo, para la necesidad de la galera, un hombre experto en vientos, llamado el piloto; su lugar de permanencia es siempre sobre la popa, y es experto en las rutas que hay en el mar y en todos los lugares donde allí haya costa. Dispone la guía de la galera al almirante, y el almirante ordena al comodoro, y el comodoro ordena al patrón y el patrón ordena a la gente. Hay también hombres agrupados en equipos; cada equipo realiza la tarea que le está encomendada, para arriar las velas o para ocuparse de cualquier faena pesada. Todos juntos colaboran para hacer su trabajo. Para cada grupo hallarás que son unos seis u ocho miembros, y sus nombres particulares son: calafates, carpinteros, proeros, cordeleros, $[\ldots . . . .]^{30}$, concari, ballesteros, fontaneros, scandoleri, remeros, barqueros; todos ellos se llaman galeotes y cada uno de ellos tiene un lugar especial en la galera, cada uno según su rango y grado, y puede hacer uso de él para su necesidad o para la necesidad de su mercadería o para alquilarlo a otros.

Escudriñé por la galera, abajo y arriba, y sus compartimentos están colmados de todo lo bueno, como el Jardín de Dios; no se hallará vacío alguno en su interior, ni siquiera encontrarás un lugar para poner el pie que no entres en lo dispuesto para tu vecino.

En su interior hallé más de 4.000 barriles, en su totalidad colmados de todo lo bueno: vino, vinagre, aceite, miel, agua y mercadería diversa. En la bodega, que es el lugar de la mercadería, hay como unos 500 paquetes, fuera de la propia mercadería que contienen, en cajones y cajas. En los compartimentos hallarás también como unas 400 arcas, pues cada viajero tiene un arca, y algunos pocos, dos.

El dueño de la nave trae, para las necesidades de su casa, como 40 o 35 corderos, dos o tres toros, cinco o seis terneras e innumerable volatería de toda clase. En todas las galeras hay abundante leña para la lumbre; en la galera no hay límite de todo alimento que se consume mucho. A un lado de la galera hay una góndola, un batelo y otra barca pequeña, todas para ir de aquí a allá si fuere preciso.

29 Es de suponer que tanto el víno como las demás vituallas y viandas son kašer, aptas para el consumo entre judios observantes de los preceptos.

30 Hay dos palabras que no hemos sabido interpretar. 
El total de los hombres que van en la galera, ya dueños, ya sirvientes, y los oficiales y mercaderes y pasajeros y galeotes, ascenderá a un total de cuatrocientas personas en cada galera.

El total del peso de todas las áncoras, cadenas y cabos, entre grandes y pequeños, que hay allí para la necesidad de la galera, me abstengo de contar pues no tiene número.

En cada galera hallarás 80 remos grandes, 40 en cada lado; y no los utilizan pues la galera es muy pesada y enorme y no se puede desplazar por la fuerza de los hombres, pues mil hombres, si la brisa no la empuja, no la desplazarían ni cuatro codos.

No se enciende fuego más que en un lugar especial para que allí cocinen los que van en la galera, sin gasto alguno. Hay un guardián encargado de la bodega, para vigilar los bienes que hay en ella, y tiene ocho sirvientes, y reciben un premio de un marcelo por cada propietario de mercadería, a su entrada, y también a su satida de la galera.

El cristiano que va en la galera, ya sea comerciante, ya sea pasajero, mientras no quiera economizar, puede agregarse a la mesa del dueño de la galera y paga un tanto fijado mensualmente y según cuenta mensual de esta manera: antes que nadie acostumbran comer, ya por la mañana, ya por la tarde, los hombres que comen en la mesa del castello, y pagan cuatro ducados venecianos al mes, que son diez marcelos de plata y un tercio cada ducado. Después que ellos han comido, comen los que están agregados a la mesa del capitán, y pagan cinco ducados cada mes. Después come la tercera ronda, que está agregada a la mesa del camarcro, y pagan tres ducados al mes. Los gastos se hacen a cuenta del dueño (de la galera) y él toma el arriendo. Comen cada vez de lo que se pone en la mesa, como un banquete de la época de Salomón, y se come, se bebe y se está alegre y festivo, y ante ellos siempre tocan los músicos: flautas, trompetas, tambores, laúd y viola, y (hay) todo tipo de deleite.

Pero ellos deben buscarse lugar para pernoctar, y lo encuentran por un tanto de cuatro o cinco ducados para todo el tiempo hasta que lleguen a Trípoli. Debes saber y comprender que la galera que va a Siria tiene dos destinos, que llaman a una la galera de Beirut, y es que pasa por Trípoli, que está lejos de Beirut cuarenta millas.

Los lugares que encontrarás en la galera son distintos (unos de otros). Primero hallarás en la popa dos camaretas pequeñas, una frente a la otra, en la parte inferior de la galera, que un hombre mediano no puede estar de pie en su interior sin encorvarse. La anchura de cada una de ellas es de dos codos y cuarto, su longitud es de dos codos y medio, y en su parte inferior hay un hueco que va desde la sentina de la galera, que en su parte media es de como un codo y medio de alto. Por los lados hay un hueco y en él podrás poner cántaros de vino, barriles de agua y de vinagre y cualquier objeto que quieras hasta colmar el lugar. Los propietarios quieren por su alquiler treinta ducados por las dos, con la condición de que los dueños se comprometan a dar agua para beber y para cocinar, cantidad suficiente para el suministro de todas las personas que van en su interior, y de todo se tiene que hacer escritura en (lengua) cristiana en Venecia, con testigos. Ese lugar tomé para mí y pagué por él treinta y dos ducados. La verdad es que en ese lugar hace mucho calor, y es lugar destinado a los hombres que vienen a traer las velas y también a sacarlas cuando quieren cambiarlas, es decir, que pasarán abajo

imagen y representación de los otros Hispania Sacra 48 (1996) 
por dentro de tus dos camaretas. De todos modos, en ellas encontré reposo, pues quien tiene mujer y pequeños las necesita; pero recuerda bien que siempre van juntos mujeres, siervos y niños, y si falta uno de ellos, su trabajo es vano.

No cambies ese lugar ni te mudes de él, pues no se halla en toda la galera un sitio como ése, resguardado de robo y daños. He aquí que el dueño del lugar debe darte agua; -no te fíes de él, sino que también tú te prepararás en tu lugar algunos barriles de agua, iquién sabe si está permitido!- para tu uso en cada momento que necesites.

En la proa se encuentran dos cabinas al lado derecho y dos al Iado izquierdo, cada una de ellas de dos codos y medio de largo, un codo y medio de ancho y un codo y medio de alto, y sobre cada una de ellas se encuentra una pequeña buhardilla como del mismo largo y ancho que la cabina, de alto como un codo y un poco más. Cada una de las cabinas y la buhardilla se alquila por nueve o diez ducados, y a veces doce. Es suficiente para dos personas y es un lugar muy bueno; los dueños de esos lugares se llaman proeros. Hay en medio, asimismo, a lo largo de la galera, como doce cabinas, de dos codos de largo cada una de ellas, y de ancho un codo y medio y lo mismo su altura; el que las quiera pagará cuatro o cinco ducados. Bajo el palo mayor encontrarás un cuarto, que es del jefe de la galera, cl cual a veces quiere alquilar, según él tenga en la popa un lugar amplio y hermoso, que son como dos cuartos, uno sobre el otro; y en particular lo encontrarás en la (galera) conserva, pues el dueño mora en un lugar que tiene el capitán en la (galera) capitana. La altura de ese cuarto es de un piso entero escaso, su anchura es de cuatro codos y medio y es un recinto oscuro. Pide por él cincuenta ducados y no conseguirás tener en su interior más lumbre que una vela dentro de la linterna, y eso con dificultad. El escribano, el almirante, el cura, el patrón y el panadero, todos tienen cuartos y cabinas. (Los precios) rondan las cantidades dichas, y a veces quieren alquilarlos y piden una cuantía de catorce ducados, algunos diez, algunos ocho, todo según su (tamaño) grande o pequeño. Bien dijeron los leguleyos: "no fijarás ley", pues hace unos cuantos años que los judíos por su parte acostumbraban dar un presente al dueño de la galera y entregarle por cada alma un ducado -lo que los incircuncisos ${ }^{31}$, por lo demás, no dan nada- y eso además del alquiler del lugar, pues lo que pagarás al oficial de la galera por el lugar de tu alojamiento no dará provecho al dueño; por lo tanto, acordaron satisfacerle dándole por cada hombre que lleva barba -y lo mismo por cada mujer-, un ducado, y los niños e infantes que no han llegado a (la edad) de instrucción, por cada dos de ellos, un ducado. Después aumentaron la cuota, y en lugar del ducado pagaban cequies, pero todo eso no les bastaba, pues desde hace veinte años que pusieron como costumbre cobrar tres ducados por cada alma, como queda dicho. Este año se aconsejaron y acordaron juntos todos los dueños de las galeras, tanto las de Beirut como las de Alejandría, cambiar sus precios y no tomar judío alguno en la galera si no pagaba seis cequíes por persona, tanto pequeño como mayor, y así debimos hacer. La verdad es que el dueño de la galera en la cual yo iba, con gran esfuerzo y mil fuerzas, viendo que yo me había ocupado de todos los que venían y también que ellos no tenían jovenes y pequeños como yo, se congració en rebajarme el pago de una persona y también de tomarme en cuenta seis ducados y cuarto por cada

31 Los cristianos. 
persona. Y esta cosa, sin duda, han puesto en territorio de Venecia como ley para los judíos, pues siempre objetaban para aumentar, pero no en poco. Quien tenga acompañantes y cerebro en la cabeza, cuidará antes hacer trato con el dueño de la galera por el pago de las personas -antes de tomar el lugar para la estancia-, pues acaso será bueno, y sin duda no causará daño, ya que siempre se encuentra lugar, incluso el día del viaje, es decir, en la ida desde Venecia a Beirut, que asimismo no está cargada de mercadería; pero a la vuelta es necesario ser de los primeros.

Y tú, mi hermano, si eligieras ir por los caminos de Dios y venir aquí camino de Venecia, presta atención y oye todo cuanto yo te digo, pues he venido a instruirte para que sepas ir por ese camino, sobre ti goteará mi palabra para enseñarte qué carnino albergará luz, tu partida y tu llegada, permanecerás firme sobre tus pies, no fuera que te atemorizases y te perdieses. No te acerques a ningún hombre en Venecia, incluso si es tu hermano ${ }^{32}$; no deposites tu confianza en ningún hombre, no creas a amigo que te guíe para sacar tu alma del encierro, pues la mayoría, tanto tú como ellos, tentarán en la oscuridad: no sabrán dónde tropezarán. Acaso haya expertos para verificar tus manos, (mas) no tendrán tiempo libre para estar siempre contigo, en tu ayuda y para sostener tu alma, pues los negocios de Venencia se suman y aumentan -cada cual se bendice a sí mismo- y especialmente en los días próximos a la salida de la galera; toda la población está alborotada y rebelde en absoluto; y a veces se da el caso que ante ti ocurre un accidente malo con falta gravísima en un instante y en un descuido: todos ellos experimenté y según lo he visto yo lo testifico. Manténte cauto en el flujo de tu dinero, y sé fuerte y compórtate como un hombre para no caer en la trampa que te tenderán. Antes que nada irás al Rialto, a un lugar que hay a su lado llamado L'Estraordinari; alií encontrarás, toda la mañana y toda la tarde, sentados, a todos los dueños de las galeras, y fibros abiertos con escribanos fidedignos para tal efecto, y les dirás: "sabed que tengo tales y cuales objetos muebles domésticos por los que no deberé pagar aduana, y tengo también tales y cuales fardos de mercadería tal, o de bienes, por los que deberé pagar aduana; hacedme dos pólizas, una que diga estas palabras: "fulano deposita en la galera tal y cual de los bienes de su casa, y los deposita en el stazzo" (stazzo quiere decir el lugar alquilado a él en la galera), pues si no escriben esas palabras en las pólizas, al tú llevar los enseres dentro de la galera, el guardián de la puerta no te dejará llevarlos dentro de tu lugar y pagarás todo por ellos, y según lo que escriban en tus pólizas así escribirán en sus libros de registro. Después, si tienes mercadería o bienes sujetos al pago de aduana, como se ha dicho, les dirás: "hacedme una segunda póliza que diga: "fulano deposita en la galera estos y aquellos enseres domésticos". Y te irás con esas pólizas a la Gabela, pues sin eso no te harán el boleto. Antes de que quieras depositar en la galera los bienes que no pagan, cambiarán el boleto con pequeños gastos, y te harán una evaluación de los bienes que pagan, y según el cálculo pagarás; puedes contar que el total que calculen (será) según lo que manifiestes: pagarás más del diez por ciento. Después pide al aduanero que te dé un inspector, el cual irá contigo a verlo todo, si tus palabras son honestas según lo que declaraste en las pólizas. El inspector lo verá cuidadosamente, y si le das un buen rega-

32 Es decir, aunque sea judío.

Imagen y representación de los otros

Hispania Sacra 48 (1996) 
lo no será concienzudo, y ante él los supervisores lo atarán todo y pondrán un sello de plomo en la ligadura para demostrar que él lo ha visto. Luego pondrás tus bienes en una pequeña embarcación para llevarlos a la galera; en tu camino de ida te encontrarás grupos de malvados y verán el boleto y los bienes sellados con el sello de la autoridad; te asustan con hacer volver todo a la aduana, a pesar de que no tienen derecho a abrirlos después de que ellos los han sellado, pero pueden decir: "¿quién sabe si el inspector no ha expoliado la aduana?", por lo tanto quieren entonces devolver todo a la gabela. No se cierre tu mano al darles dinero de propina y nos les ocasiones enojo, pues te equivocarás del todo y es pérdida de tiempo, y los gastos de la vuelta ascenderán a una gran cuantía. Yo gasté en ellos más de tres escudos de oro, topándome con unos veinte grupos de ésos. A quiénes di un marcelo y a quiénes di un mocenigo, y no se apartaron de mí hasta que dejaron Jimpio el fondo de mi bolsa.

A tu llegada a la galera entrega el boleto en mano del guardián de la puerta de los bienes, que está escrito en la póliza que dice: "en el camarote". Él en persona con su compañero te introducirán en tus aposentos, y los bienes inscritos en la póliza, "en la bodega", los llevará dentro del lugar escondido de las mercancías; él se quedará con todas las pólizas y en su lugar te dará un recibo de los bienes que quedan en su poder, el cual recibo guardarás contigo hasta tu llegada a Trípoli, pues no te devolverán los bienes sin él a no ser con gran forcejeo. No te apoyes en quienes te digan: "hoy zarparán las galeras", o "no se irán hasta mañana". Se dice de esto: "anticiparse y no retrasarse"; por lo tanto, sé tú de los primeros en depositar tus bienes en la galera y no te retrases, por dos razones: pues en el momento de zarpar -asimismo un día o dos antesse multiplica la gente para llevar (cosas a la galera) y a veces no tendrás tiempo para aproximarte a ella media milla, debido a tantas embarcaciones quc hay a su alrededor, y cuando estés a bordo de la galera encontrarás todo repleto, abajo y arriba, y a veces tú mismo no podrás caminar por tu propio pie, a bordo, ni cuatro codos. Otra segunda razón: pues si acaso te retrasares en ir encontrarás que ya se fueron de la costa e hicjeron una milla -y no te servirá de nada gritar, pues no contestarán y no se detendrán por nada-. Tendrás que tomar una embarcación desde la partida con un gasto superior a diez escudos de oro, y más, hasta Pola.

Bueno es que sepas que todos los paquetes que son mercadería, o que por ellos pagues aduana en Venecia, aunque no sea mercadería, a pesar de que tengas en tu aposento lugar libre para guardarlos, el dueño de la galera no querrá dejártelos contigo si no pagas por ellos el canon acostumbrado, pues así es la ley, y si pagas por ellos el canon debe tomarlos consigo, si quieres, y ponerlos en la bodega con los demás efectos de la mercadería. El monto del canon por el paquete no es fijo, tan sólo se paga según Ios bienes que contiene; yo tuve que pagar en Venecia, por cuatro paquetes de vestidos de lana y fustanes que llevaba, todos, para mis necesidades de casa. Lo cierto es que todo era nuevo, y pagué por ellos un canon aduanero de doce escudos de oro en oro, pues los valoraron en doscientos escudos, y por el canon de ellos en la galera pagué seis escudos de oro. El total de dinero que lleves contigo en la galera para pasarlo de país en país se rige por una ley única e igual para todos, sea hebreo, sea cristiano, sea togarmí, y es que debes declararlo al dueño de la galera, y por ello pagarás un canon del uno y cuarto por ciento. Si quieres tenerlos tú, puedes; si quieres depositarlos a su 
custodia, él deberá guardártelos (bajo) estricta vigilancia y devolvértelos en Trípoli o en cualquier lugar que quieras del trayecto; si se los cuentas él también te los devolverá contados, y si los pones dentro de un paquete sellado, te lo devolverán como tal; te escribirá en las pólizas que te hagan: "tanto y cuanto dinero, según sus declaraciones"; de todos modos, recibirás las pólizas y las tendrás en tu custodia hasta que recibas de sus manos el paquete o el dinero; abre tus ojos para ver que las pólizas especifiquen cómo es el pago del canon -si lo pagaste antes-y en sus registros de depósitos escribirá como está escrito en las pólizas, letra por letra, sin ninguna diferencia, y haz una señal sobre el paquete, como sc te ocurra, para reconocerlo, pues tal hará él sobre las pólizas y sobre el paquete también.

Debes saber y comprender que por el camino, antes de que salgas de la galera, te harán jurar si tienes alguna cantidad de dinero que no declaraste; tras tu llegada a Trípoli, antes de que salgas, registrarán minuciosamente tus vestidos y lo que tengas en el cuarto donde tú duermes y en tu cama, y si te encuentran alguna cantidad de dinero que no declaraste, lo confiscarán, pues así está dispuesta la ley, que se consideran perdidos para ti sin ningún remedio; por lo tanto, entiende bien lo que hay ante ti, pues el sabio tiene ojos en su cabeza: no infrinjas la aduana porque lo perderás todo. He aquí que encontrarás a muchos que te dirán que no hay temor de peligro en la cuestión: no quieras ni escuches la voz de hechiceros, pues la mayoría de los ciudadanos compran la galera, como se ha dicho, y aunque son príncipes honorables, a menudo tienen rencillas entre ellos y compran el alquiler de la galera por más de lo que ellos sacan de ella (de beneficio) y pierden, se cubre su alma de amargura, si encuentran a un hombre que infringe las ordenanzas, especialmente judío, no le perdonarán ni tendrán compasión.

El dinero que debas dar al señor de la galera en concepto de aduana personal, así como por los bienes y por los caudales, e igualmente lo que debes dar a los patrones en concepto de alquiler por aposento, si te lo pidiesen para recibirlo en Venecia, se lo podrás dar, pero recibirás de ellos justificante por escrito. Allí te tomarán el escudo por una libra 18 sueldos, y los cequíes por 8 libras 14 sueldos, en moncda de Venecia, y si tardas a pagar en Famagusta o en Trípoli, no tomarán por escudo más que 6 libras 17 sueldos, y los cequíes a razón de 8 libras, todo según las costumbres de la ciudad; además es que si les pagases en Venecia harás bien y certeramente a sus ojos, puesto que con esos dineros compran cosas para la mercadería y por tu causa les llega provecho, y no acaecerá ningún đaño.

Prepárate para las necesidades de cada persona: medio escudo de bizcochos, como un marcelo de pan, una carga de vino, tres tarros de viangre, carne seca, queso, huevos, sal, diez cirios, una linterna, recipientes de cobre, legumbres variadas, ajos, cebollas.

Favorece el corazón del panadero para que te prometa que te dejará un lugar en el extremo del fuego ${ }^{33}$ y que no permitirá a nadie que te haga daño. Guarda tu alma de posible trampa y ten en tus manos alguna cosa que quieras darle hasta el momento de tu partida de él en el momento de tu llegada a destino. Todos los hombres que van do.

33 Juicioso consejo, pues la preparación de las comidas kašer debía correr a cuenta del interesa-

Imagen y representación de los otros

Hispania Sacra 48 (1996) 
dentro de la galera, en su mayoría, son hombres de espíritu amargo y sanguinario, codiciosos y tramposos, en cuyas palabras no podrás tener fe, y cuida de ir con ellos, del bueno al malo; si uno de ellos te habla ásperamente haz tus oídos como embudos, no respondas tontamente como su insulto o contéstales con lengua suave. A los hombres que están frente a ti, cerca de tu aposento, abre tu mano contestándoles con lo que Dios te concedió, pues te harán servicio y a veces te honrarán. De todos modos, no pongas tu confianza más que en nuestra Fortaleza de Dios; cuida tus pies cuando camines, pues pondrás tus ojos en el bolsillo y caminarás en la rectitud. Si quieres provecho no te reveles como indigente, ya que prodigarás tu dinero con los jefes, con el capitán o con el dueño de la galera; aunque sea cosa conveniente y aceptable considerarán todo como minucia -tal es su arrogancia- y la mayoría te dirán: "tanto tienes, tanto vales".

No he tenido un día tan bueno como el 15 de ' $\mathrm{Ab}$, día cuarto para el sábado, 4 de agosto (de 5.) 323 del gran cómputo, en el cual salimos de Venecia, la capital, para ir a la Tierra de Israel en un grupo de cinco galeras juntas, tres de ellas para Alejandría y dos para Beirut, y en cada una de ellas iban muchos judíos. Yo tomé un lugar en la capitana, en la bodega, a proa, un lugar destinado al calafate y al carpintero, como he apuntado antes.

Todas las galeras fueron juntas mil cien millas hasta un lugar que está cn la isla de Candía ${ }^{34}$ y se llama Capo Spada ${ }^{35}$. A partir de allí se separaron en dos grupos: las galeras de Alejandría hicieron su camino a Candía, ciudad del reino en medio de la isla, y nosotros salimos fuera de ella y nos internamos en el mar cuarenta y siete millas. El trayecto que hicimos desde Venecia hasta Pola es de cien millas, pero el mismo trayecto es de más de ciento cincuenta millas, y la vía marítima que hicimos es la que rodea los países de Istria.

Allí (en Pola) nos detuvimos siete días. Pola es una gran ciudad y tiene pocos habitantes; es larga y estrecha, muy fea, y no se encuentra en ella cosa buena y cl aire es muy perjudicial. Según se oye decir, sus aguas son malas y el país mortífero. Muchas veces bajé a ella y no hallé que comprar ninguan vitualla, ni siquiera pan. Fuera de una puerta encontré un cortijo antiguo, desolado, con un manantial a su lado; dicen que fue el palacio de Orlando, edifícado en círculo como la Retonda de Roma; y dicen que su edificación fue obra de genios maléficos u obra de encantadores ${ }^{36}$.

Allí los dos capitanes de las galeras acordaron entre sí que cada uno de ellos mandaría durante una semana, y nuestro capitán comenzó la primera semana yendo delante, y la última viajarían con sus banderas atrás, como la conserva, siempre viajan los últimos; al despuntar el alba del jueves 13 de agosto, $25 \mathrm{de}$ ' $\mathrm{Ab}$, fuimos a nuestro camino y atravesamos todos los países de Esclavonia, cerca de muchos lugares como Zara, Ragusa, Zirona, Cattaro, Castelnuovo, que está bajo el poder del togarmí -su gloria sea ensalzada-, y cuando se terminaron los países de Esclavonia entramos frente a los países de La Albania, frente a La Valona, hasta que llegamos a Corfú.

34 La isla de Creta.

35. Es el cabo Spatha, al occidente de Creta.

36 Esta tradición la recogen Benjamín de Tưdela (1165) y más tarde R. Mošeh Basola (1521). Vide MAGDalena NOM DE DÉu, José RAMón: Relatos de viajes..., p. 17 !. 
A mitad del trayecto se nos presentó una tempestad marina para hundirnos, con gran marejada, y nos golpeó durante tres días y tres noches, cubriendo de agua nuestras cabezas de tal modo que temíamos por nuestras almas. Imploramos a nuestro Dios fuertemente y escuchó la voz de nuestras súplicas apoyándonos en Él, y se calmó el mar en su furia, se callaron sus olas, y con buen viento fuimos hacia Corfú el jueves 19 de agosto, primero del mes de 'Elul. ¡ßBendito Aquél cuya piedad nos maravilló en día de angustia!

A 30 millas lejos de Corfú topamos con doce galeras vacías, de la guardia de Corfú, que venían hacia nosotros como es su costumbre. Qujen no ha visto la alegría de la multitud regocijada y el estruendo de la artillería que hicieron las muchas y pesadas galeras al unísono, el toque de las trompetas, trompas y clarines, que sonaron, tocaron y resonaron durante más de media hora, no ha visto alegría en su vida. Después pusieron ante cada galera las nuestras dos galeras vacías que nos arrastraban tras ellas mediante cabos, y en cada galera vacía hay doscientos remos que los galeotes, con su gran fuerza, mueven en el mar temolcándonos con rapidez. La galera del proveditoro-que es el jefe de la guardia- iba delante, y todas las demás tras ella, una tras otra, y otra de las vacías iba en último lugar. Doce lanchas nos rodeaban por aquí y por allá, unas veces por delante y otras por detrás, hasta que ese día, a la hora de comer, entramos a la costa de Corfú.

En seguida entré en la ciudad a comprar un poco de pan y comida. Allí encontré también a los jefes de dos comunidades de judíos, entre todos son como unos setenta propietarios de casas, en su mayoría sicilianos y poleses, algunos (de ellos) son prestamistas, otros pocos son tintoreros, algunos otros son curtidores y artesanos de mercería. En ese lugar no hay temor de Dios; entre ellos no hallarás Ley ni respeto, grande es la enemistad en su entorno, iguay de ella!. Lo que les des a comer darán testimonio que es malo, como ellos mismos testimonian su maldad y sus pecados, dirán que no todos a una, y se jactarán en la ciudad de que tal hacen. A mi llegada a la ciudad encontré que sacaban a tres muertos al sepulcro de una vez. Les reproché para que sacaran uno tras otro, como es debido ${ }^{37}$, y no me sirvió de nada, pues me respondieron que no tenían tiempo para volver una segunda y una tercera vez, y tienen su cementerio dentro de la ciudad.

Desde Pola hasta Corfú hay un trayecto de seiscientas millas. Corfú es una ciudad que se asienta en parte en un valle y en parte en un monte, es grande como Ancona, y tiene una fortaleza grande, fortificada y hermosa en la plaza de la ciudad y también al lado del mar, con doscientos mercenarios italianos para guardarla, además de quince galeras vacías que están allí permanentemente y rondan el mar para guardarlo de los piratas. (Corfú) es muy fea, sus caminos están sucios, sus callejuelas son inmundas y sucias debido al barro y al fango, sus aguas son malas y sus vituallas muy caras, y con dificultad hallamos para comprar (cantidad) suficiente para (cubrir) nuestras necesidades. El pan es negro y no está del todo horneado y está lleno de piedras y polvo, debido a los molinillos, pues no tienen molinos para moler. Del mismo modo encontrarás el

${ }_{37}$ Nuestro viajero recrimina a sus correligionarios de Corfú la incorrecta ceremonia de inhumación de cadáveres, lo que indica sus conocimientos de halakah.

Imagen y representación de los otros

Hispania Sacra 48 (1996) 
pan en Zante, pues ciertamente no se lo puede comer. Allí había sandías en abundancia y no son parecidas a las nuestras, pero son dulces y buenas. Hallamos abundancia de carne de toro, pescado salado, uva mala y agria, legumbres, cebollas y muchos ajos y cosas por el estilo.

Desde allí salimos el lunes 23 de agosto, 4 de 'Elul, pues nos detuvimos alíi, según es su costumbre, tres días después de que salieran juntas todas las cinco galeras pesadas, y con nosotros vinieron asimismo quince galeras vacías para acompañarnos durante un trayecto de cuarenta millas hasta una costa llamada San Nicolo, y desde allí regresaron a su lugar en paz. Nosotros nos dirigimos a nuestro camino vía Albania, hasta nuestra llegada a Zante, a doscientas millas lejos de Corfú, el jueves 26 de agosto, 7 de 'Elul (del año judío 5.)323. (Zante) está en la parte baja de la montaña; es país extenso, limpio y bueno, y en particular colmado de buen vino y aceile, miel preciosa, toda hermosa, sus frutas son dulces; pescados, huevos, volatería en abundancia, no falta dc nada en ella; allí se encuentra el queso kašer en abundancia, pero lodas las cosas se venden caras. La verdad es que escuché que dicen que la venida de las galeras provocó esta carestía.

A intramuros hay una sinagoga de judíos, que son como unos veinte propietarios de casas sicilianos y portugueses ${ }^{38}$, todos ricos; prestan a una ganancia del veinte por talento, pero según parece no es su intención dedicarse a prestar, pues con la mercadería obtienen mucha más ganancia y colman sus casas de todo lo bueno con escaso gasto; desdeñan toda gratitud hasta que han olvidado al Dios de su salvación, estando seguros en su gran poder y en su gran riqueza se vanagloriarán. En verdad de la buena, cuando vi la sinagoga de ellos, que está destruida y desolada por dentro como una encrucijada de caminos, los cuervos van allí siempre y toda cosa impura entra dentro, afligióse mi alma pues no la reconocí, -excepto el honor de la presencia divina- si aquello era casa de barro o establo de ganado. Allí, a veces, se congregan diez orantes en sábado, según venga la ocasión, y los restantes días profanos se vuelven orgullosos y descarriados falaces, a su camino se dirigirán, cada uno a su extremo de codicia, iguay de sus almas! pues eligieron habitar en las tiendas de la maldad, tabernáculos de iniquidad ${ }^{39}$, sus almas están dentro de los que se vuelven griegos impuros, y han aprendido de sus (malas) acciones. Me han contado que en su mayoría sacan pocas reses inhábiles de las que degüellan, y a petición mía degollaron una ternera y la consideraron kašer; yo la inspeccioné tras el bodeq y hallé cn sus pulmones una impureza adherida a la grasa del corazón ${ }^{40}$. Eso es difícil, pues no es bastante que no (hay) confusión y caos debido a los primeros, que cometieron iniquidad y pecaron, sino que murmuraban entre ellos y oí que decfan: "de ahora en adelante nos guardaremos de degollar ante ningún erudito". Quien estima su alma se alejará de ellos, y los obscrvantes de la Ley se enojarán con ellos ${ }^{41}$.

38 Acaso son los expulsados de la Península Ibérica en 1492. SchwaB dice "ou de Tunis".

39 Salmos LXXXIV, II, Job XVIII, 21.

4i) Experto en cuestiones de halakah, nuestro viajero pone reparos a la idoneidad de las reses sacrificadas e inspeccionadas por sus correligionarios de Zante.

41 Proverbios XXII, 5. 
Nos demoramos en Zante cinco días y el día martes 31 de agosto, 12 de 'Elul (del año judío de 5.) 323 nos pusimos en camino y pasamos cerca de Modón -está lejos de Zante ciento cincuenta millas- que está a medio camino de Venecia a Famagusta; desde allí fuimos tres millas hasta que Ilegamos a un lugar llamado Capo Spada. Allí nos separamos, pues la galera de Alejandría se fue de ante la isla para llegar a Candía, y nosotros circunvalamos toda la isla por fuera, como trescientas millas; toda la isla tiene una circunvalación de setecientas millas. Después nos internamos en el mar unas siete leguas y pasamos el golfo, que es de quinientas millas, donde nunca vimos continente en medio del golfo. Estuvimos dos días y una noche vagando en el mar debido a una tempestad que comenzó a confundirnos. Posteriormente, hizo Dios salir un buen viento de sus contenciones y la embarcación fue conducida con tranquilidad y scguridad hasta que arribamos al inicio de la isla de Chipre, como a veinte millas lejos de Famagusta; allí topamos cuatro galeras vacías de la guardia del lugar que venían hacia nosotros como es su costumbre. El sábado santo antes de primero de año - 11 de septiembre (de 1.563-, del año judío 5.)324, entramos en la costa de Famagusta, a mil trescientas millas lejos de Zante. Tendrás exactamente, desde Venecia hasta Famagusta, que hay dos mil doscientas millas.

Al llegar nosotros allí escuchamos -y se conmovió nuestro vientre- que todos los países de Siria están afectados por una plaga y una peste, pues la mano de Dios estuvo en ellas para agitarlas desde el mes de 'Adar primero en adelante, particularmente en Jerusalén -ciudad santa-, en Safed -sea reedificada y reconstruida-, en Alepo, en Damasco, y también en Beirut y Trípoli ${ }^{\mathbf{4 2}}$.

Se nos hace verdadera la creencia entre nosotros que en todos los lugares se ha detenido la peste desde que se inició hasta ahora, pero no ha desaparecido en absoluto, excepto en Trípoli, adonde allí enviaron una fragata al inicio (de la peste) y en dos días fue, regresó y certificó que (la ciudad) está del todo limpia.

Me entró temor al oír el rumor de este mal, pues temí ir allí, no fuese que-¡Dios no lo quiera!- se me contagiase el mal y muriese y pereciese, yo y mi casa. La galera se detuvo aquí seis días y el día de $R o s ̌-h a-s ̌ a n n a h^{43}$, antes de la mañana, hicieron su camino hacia Trípoli, y llegaron alíi al día siguiente, día segundo después de Roš-hašannah, que es un trayecto de cien millas. El excelentísimo honorable Selomoh da Pisa -le guarde su Roca y Refugio- y un erudito aškenazí que va a Jerusalén con sus familiares, y tres levantinos que van a Safed, y un anciano sefardí que vino conmigo desde Pésaro, eligieron ir con la galera, ¡Dios les haga tener éxito en su camino y les guarde de toda aflicción y desgracia y del demonio exterminador, y con su mucha piedad y bondad los defienda, proteja y se apiade de la evacuación de su pueblo Israel y aparte de ellos esta desgracia, así sea su voluntad, amén!.

Me quedé aquí yo solo, y conmigo se demoró asimismo R. Yishaq Pulieso -le guarde su Roca y Refugio-, que vivía en Ferrara, pues no quisimos ir hasta que se

42 A lo largo del siglo XVI, diversas epidemias se cebaron entre la población de la Palestina otomana: 1523-1525, 1533, I550, I563, I572 y 1594. Vide BEN-ZVI, IZHAK: Eretz-Israel under Ottoman Rule. Four Centuries of History. (en hebreo) Jerusalến 1968 ${ }^{2}$, pp. 174-175.

43 El 18 de setiembre de 1563.

Imagen y representación de los otros

Hispania Sacra 48 (1996) 
oyese voz de buena nueva de paz y esperase Dios a salvar a Israel; me dije a mí mismo: "el astuto ve el mal y se esconde"44. Me favoreció Dios y dio mi gracia a los ojos de los hombres de esta santa comunidad y me rogaron que morase entre ellos algunos días. He aquí, pues, que "esta ciudad está cercana"45 para ir a mi destino más que Trípoli y que Rodas, pues se asienta en el ombligo del mundo, como ya te he dicho; desde Rodas a Trípoli hay cien millas, de aquí a Beirut ciento veinte millas, de aquí a Sidón ciento cuarenta millas, de aquí a Acre doscientas millas, que desde aquí a Jerusalén hay un trayecto de día y medio por tierra, que son como cuarenta millas. De aquí a El Cairo hay un trayecto de doscientas cincuenta millas, de aquí a Constantinopla trescientas millas. Todos los trayectos son mediante navío, en el corazón del mar, y en todo momento y en todo tiempo zarpan galeras para ir allí y allá, como se encuentra en nuestras comarcas a diario una embarcación que va desde Pésaro por el camino de Venecia. Y es que hay una ínsula que rodea a la mayoría de las ciudades que he citado, desde aquí hasta Jerusalén, como te mostraré en los márgenes de esta epístola ${ }^{46}$ para que te ilustres y comprendas todo cuanto te he descrito; el gasto del trayecto marítimo es una minucia, pues por ocho o diez ducados todo lo más tomaré una embarcación como al principio para llevar en su interior a todos los miembros de mi casa y todos mis bienes, desde aquí a Acre o desde aquí a Yafo, según yo elija ir. Desde allí en adelante hay un pequeño trayecto por tierra, que no gastaré (en él) cinco o seis ducados. Es la costumbre que la mayoría viajan desde aquí el martes o el miércoles de cada semana y se encuentran en la sinagoga el sábado, en Safed o en Jerusalén. La verdad es que los judíos se guardan de ir durante el verano a Yafo y también a Acre, porque temen a las galeras maltesas ${ }^{47}$. Los hay que no prestan atención a ello, diciendo: "Dios asiste a su manera y preserva de simplezas" 48 . Pero al entrar el mes de octubre, hasta todo el mes de marzo, no hay temor y se va seguro, con la ayuda de Dios, bendito sea.

El que quiere ir desde Trípoli a Safed necesita ahora ir antes a Damasco, que es un trayecto de tres días, y desde allí a Safed hay un trayecto de otros tres días, y necesita demorarse en cada lugar muchos días para esperar a la compañía que va de lugar en lugar; dicen que ahora el camino es más peligroso de lo que era antes, y el gasto es gravoso. Me dijeron que no bastan ochenta escudos de oro para llevar a los de mi familia y mis pertenencias por ese camino.

Por el camino hay varias fronteras ${ }^{49}$ y en cada lugar tienes que pagar por cada persona, a veces diez y a veces ocho mayadies; la aduana de Trípoli es gravosa, y tampoco la aduana de Damasco es liviana. Lo que pagué para llevar a los de mi casa, que son siete personas -les guarde Dios, y les salve, amén- los enseres y el gasto de manutención en Venecia -que allí me demoré catorce días-, entre todo desde Pésaro hasta

\footnotetext{
44 Proverbios XXII,3

45 Génesis XIX,20.

46 El croquis está en el fóìo 124 verso del ms.

47 Es decir, de los corsarios cristianos de la isla de Malta.

48 Salmos XCVI,6.

49. Son lugares de peaje y pago de tributo de paso.
} 
Famagusta, he mantenido una cuenta justa que fueron ciento sesenta y nueve escudos y un cuarto de oro, en oro.

Famagusta se asienta sobre la orilla del mar, toda ella es una llanura; es ciudad fortificada y fuerte y tiene dos murallas, milicia y muro, y es parecida a Pésaro, con una gran urbe, hermosa y muy fuerte. La autoridad mantiene allí siempre cinco galeras vacías para guardar el mar, y cuatro compañías en la ciudad para su custodia con ochocientos mercenarios italianos, y todos los ciudadanos son limpios y se cuidan de toda cosa mala y en particular se cuidan de la peste, estando en medio de los países del togarmí, y se cuidan mucho de sus almas, como en Italia. No permiten la entrada en la costa a ningún hombre que viene de lugar recelado, sino después de retenerło, según la ley, durante cuarenta días ${ }^{50}$. Las casas de aquí son buenas y hermosas y el orden de sus caminos y la manera de distribuirlos es como en las provincias latinas; los bienes se venden en dos zocos y frente a la Corte del rey hay una gran plaza muy hermosa. HaIlarás manantiales de aguas resurgentes en cada encrucijada. La moneda que corre aquí es la veneciana de toda clase y el escudo cquivale a seis libras y dieciséis sueldos de moneda de Venecia, el cequino equivale a nueve libras, pero el escudo que no es de Venecia no equivale más que a seis libras y nueve sueldos.

Dicen que aquí no cae nieve y nunca se encuentra hielo, e incluso las precipitaciones de lluvia y rocío son escasísimas. El calor es aquí mayor que en todos los países de Ismael ${ }^{51}$. En los días de verano no se encuentra a nadie de puertas de su casa afuera sino una hora por la mañana y una hora por la tarde, y el verano dura como unos ocho meses al año. Si quieren ir de una ciudad a otra no cabalgan más que por la noche, y ésta es la costumbre de las personas que desean conservar su salud.

Acostumbran hacer uso de un carro con bueyes para llevar los bienes de un lugar a otro, pero el carro no es parecido al nuestro, y las bestias son también (de piel) manchada y rayada. Pensé que aquí estuvo nuestro patriarca Jacob -la paz sea con él-. Para cabalgar hay abundancia de caballos y asnos. Recibirás un buen caballo con un gasto de alquiler del cuatro por ciento diario, y las raciones para las bestias son baratas.

Hay aquí muchos enfermos de $\operatorname{los} \operatorname{ojos}^{52}$, empieza en la época de Tammuz hasta toda la media temporada de Tišry, y los inicios de la enfermedad son fiebres cada dos días, o tercianas, con gran dolor; a veces continúa la enfermedad veinte días o un mes, y con buena vigilancia se cura. La mayor parte de la gente están afectados de esta enfermedad, mujeres, pequeños y también mayores. Estamos nosotros ahora a mitad de octubre y todavía no podemos soportar la sábana sobre nuestro cuerpo, ni siquiera por la noche, debido al gran calor. El alquiler de casas es aquí como en Italia; yo he tomado una casa que tiene dos cuartos grandes, hermosos y buenos, en la parte superior, con cocina, y un cuarto en la parte inferior, como almacén, bueno para el vino, el aceite, la leña y para lugar de la volatería, por una cuantía de diez ducados anuales. Tú

so Curiosa observación sobre las cuarentenas preventivas en caso de peste o epidemia.

s1 Los países islámicos.

s2 Otra sagaz observación de carícter médico, que describe perfectamente nuestro viajero. 
mismo no puedes ir a la fuente para tomar agua, pues los griegos y asimismo los galeotes te afligirán y te romperán el cántaro, pero a cada momento pasan por los alrededores azacanes y llevarán a tu casa un barril por dos cuartinos, suficiente para beber y cocinar un día.

Aquí encontré una sinagoga grande y hermosa y engalanada, con una congregación que es de como unos veinticinco propietarios de casas, unos pocos levantinos 53 , unos pocos sicilianos y unos pocos portugueses ${ }^{54}$. Hay entre ellos odio, envidia, rivalidad y enemistad, y en el seno (de la comunidad) no hay pobres que se sustenten de la caridad, y si se presenta un mendigo forastero, no le harán bien como en Italia. No tienen carga ni impuesto, sino veintiséis ducados anuales que dan al juez de la ciudad por toda la comunidad, y todos comen con abundancia y sin estrechez; no tienen más dedicación que el préstamo a usura, salvo dos o tres pobres que no tienen dinero para prestar, pero son corredores y ganan bien, sin faltarles nada bueno.

No hay en toda la isla, en ningún lugar, judíos más que aquí. (La isla) es grande, que contiene como unas dieciséis mil aldeas llamadas casales, además de la gran ciudad que es metrópolis del país, Ilamada Nicosia, lejos de aquí treintaiséis millas, un trayecto de día y medio, y todos vienen aquí para empeñar debido a que encontrarán. En verdad que el asunto del préstamo es aquí maravilloso. No prestan a nadie excepto sobre hipoteca segura. Aquí no hay fe ni hombres (fieles). Si la prenda hipotecaria es de oro y plata, toman (a razón) de veinte por talento; si es prenda de lana o fustán o seda, o mercadería u otra cosa, toman (a razón) de veinticinco por talento. Retienen la prenda un año, luego envían reclamación al propietario de la prenda -a sus costas- para que venga a rescatarla o para renovar[la] en un [cierto] plazo de días. Si no viene, envían la prenda al tribunal rabínico y la venden en subasta. Si el dinero (obtenido) es suficiente para todo lo necesario y sobra, es decir, para el fondo, ganancia y gastos, entonces se devuelve lo sobrante a los dueños (de la prenda); si no es suficiente se regula su cómputo y lo que le falta hasta el pago de lo que debe recibir, el tribunal rabínico le escribe una nota del total ése y lo entrega en mano de un sayón que rápidamente va a la casa del incircunciso y toma de él una segunda prenda, y conocida, para dar al judío el suplemento de su pago.

No se encuentra tienda abierta y un judio no está más reconocido que otro; quien quiere prestar irá y prestará, se arreglará un cuaderno para anotar las prendas, lo llevará ante el juez y se lo sellará con su sello del reino, y entonces será ciertamente como un documento legal.

Cuando los incircuncisos ven aquí un judío nuevo que viene a morar, le preguntan si quiere dar a préstamo; si dice que sí, le estimarán mucho, y no hay que temer que los judíos le controlen con mal ojo como (si fuese) un advenedizo, pues el país es extenso y ellos mismos le indicarán para que preste a algún amigo de ellos, si ellos no tienen para darle como es su costumbre. En verdad hará aquí préstamo(s) de más de cincuenta

53. Judíos de Palestina y Siria.

54 Judios sefardíes, oriundos de la Península lbérica expulsados en 1492. YA'ARY dice ponentini.

Imagen y representación de los otros Hispania Sacra 48 (1996) 
mil (monedas) de oro en seis meses. No es accidental, antes bien fundamental, que hay aquí una costumbre bonita: antes de que les des dinero sobre la prenda te traen un presente, aunque no quieran más que un escudo, y traen una gallina o dos, un cordero, un cabrito, un capón, un ternero, vino, trigo, aceite, todo según la cuantía del dinero. Lo cierto es que cuando la prenda es de gran valor, no traen un gran regalo, según (hacen) con el valor de las pequeñas, pero darán una buena porción. Valdrá para un año, cuanto menos, (a razón) de tres o cuatro por talento. Es una costumbre fija y un arreglo a pesar de que no tiene soporte de la Torah y aunque no se encuentre escrita en las leyes del reino. Esta costumbre aquí anula a la Halakah, y no necesitarás preguntar, pues sobre ella vendrán ${ }^{55}$. Yo he dado a préstamo todo el dinero que traje a un tiempo de diez días, todo sobre plata y oro, y no he querido tomar prendas de paños; tampoco he querido hacer hipoteca superior a cincuenta o inferior a treinta; a veces el corredor judío -que es el mediador para entregarle el dinero- quiere ser pagado por el incircunciso en mucho y nosotros nos contentamos con poca cosa de manera que los incircuncisos pagan a veces más de cuarenta por talento. No hay ninguna maledicencia en la ciudad, ya que también ellos ${ }^{56}$ están contentos de encontrar para empeñar en sus momentos de necesidad, y cada trabajador y cada artesano tiene objetos de plata y joyas, pues todos ellos son ricos.

Aquí he encontrado al gran hombre, grande en Torah y en sabiduría, esplendor de la generación, honorable señor nuestro maestro el rabino 'Eli 'ézer 'Aškenazís7 -le guarde su Roca y su Refugio-; él es quien va a vuestro encuentro con éstas mis epístolas a Venecia, y va a recibir a su nuera, la hija del sabio el íntegro honorable señor nuestro maestro el rabino Šemu'el Yehudah -le guarde su Roca y su Refugio- hijo del sabio excelentísimo rabino Me'ír da Padova ${ }^{58}$-guarde su misericordia y bendición-, a quien tomó para su hijo -le guarde su Roca y su Refugio-; él tiene cincuenta años y fue juez de todas las comunidades de Egipto (durante) veintidós años, y por causa accidental debió salir, y escogió quedarse aquí con los de su casa, y hace como unos dos años que ya fijó lugar para su vivienda aquí. Es experto en doce lenguas, grande para los judíos y sabio en muchas sabidurías extranjeras, y en Talmud entiende diez manos, es rico en más de cinco o seis mil (monedas) de oro - ¡haga Dios con él piedad!-, pues desde que yo liegué de Venecia no he encontrado hasta ahora a un hombre de Dios como él, y hallé reposo en su casa. Suplica para acompañarme y ayudarme en todo trance posible, tanto me quiere, y yo me he adherido a su sabiduría, pues casi hoy

5.5 La larga digresión de nuestro viajero sobre la cuestión de los préstamos tiene su interés, pues resulta que el "regalo" del prestatario al prestamista es práctica consuetudinaria en aquellas latitudes $\mathrm{y}$, aunque no se contempla en la halakah hebraica ni en las leyes escritas de Chipre, en opinión del de Pésaro, suple a la legislación rabínica, es decir, no encubre usura prohibida.

st Evidentemente, los cristianos.

57 Este rabino -autor de un comentario al libro de Ester y otros libros históricos de la Biblia- se trasladó posteriormente a Cremona y murió como gran rabino de Cracovia en 1586. Vide JoST, J. M.: Schreiben..., pp. 30-31 la larga nota 25 .

58 Acaso Mošeh Me'ír ben 'Efra'ím da Mantova, escriba, impresor y maestro en Mantova. Falleció en 1583.

Imagen y representación de los otros

Hispania Sacra 48 (1996) 
mi corazón se inclina a morar aquí durante dos años y estudiar con él Torah, pues éste es lugar razonable para mí.

Podré determinar los tiempos de día y de noche y si también cayese la casa no prescindiría del estudio ni una hora del día. Seré fiel con él y me estimará como un padre a un hijo, extenderá sus alas para salvarme de toda maldad y ya me he hecho su compadre, pues le nació un niño y me hizo padrino de la circuncisión.

No hay almas de Dios entre este pueblo, pues son hombres de fortuna y engaño y no mantienen alianza con nadie; son huecos y soberbios y no hay frente a ellos temor de Dios, de manera que su excelencia se alegra mucho estando conmigo, y la casa donde yo resido está próxima a la suya: todos entramos por la misma puerta, y ninguno de nosotros sale afuera si no es en las horas de la oración. Para mí es duro separarme de él estos días que se retrasará para ir y estar en Venecia un mes. ¡El Ubicuo le devuelva a su casa en paz, amén, así sea su voluntad!. Si pudiese hablar con Dios le pediría que tocase el corazón de los hombres decentes de las regiones de Italia para que decidiesen venir con nosotros para morar aquí, pues no hay mejor que esto para ellos y para sus descendientes, y si tal hombre elige acercarse a morar en los cortijos de Famagusta, comerá manjares regios - como frutas con nardos-y tendrá tiempo para servir a nuestro Dios en la Torah y con voz de cántico; obtendrá su alimento con holgura, pues en verdad que los habitantes de aquí son de los que comen el maná. Si su corazón se dedicó a frecuentar los patios de Dios y morar en Jerusalén, ciudad santa, o en Safed -sea reconstruida y reedificada con presteza en nuestros días-, subirá y podrá arreglar negocios de modo que desde este lugar podrá recibir suficiente sustento dejando aquí sus caudales oportunos y de sus frutos comerá y se regocijará.

En eso se aflige mi corazón porque soy el único aquí, pues si encontrase aquí un amigo personal adecuado para prometer en eso que fijaría su morada, he aquí que haría fiesta y acaso decidiría dejar aquí parte de mis familiares y en esa ocasión, para el año que viene, subiría a lo alto del Monte de los Olivos para cumplir mi voto ${ }^{52}$, y esta parte que queda de mi campamento me servirá de refugio ${ }^{60}$.

Contaré por extenso el elogio de esta comarca y también su vituperio, según lo que he visto con mis ojos, para que te itustres en la cuestion, sepas lo que has de hacer, y Dios esté dentro de ti. Los cristianos que moran en toda la isla de Chipre, Candía, Corfú, Zante, Constantinopla, son en su mayoría griegos, y no son como los cristianos italianos ${ }^{61}$. Carecen de entendimiento, sus creencias son diferentes de las de todos los pueblos y sus disposiciones varían; no hacen las prácticas ni las costumbres de los cristianos y no dan crédito al rey de Roma, pues tienen un Patriarca en Constantinopla que les gobierna -a él se dirigirán los gentiles-, en sus iglesias no hallarás campana, y tienen muchas leyes que no aceptarán los italianos.

En la ciudad hay unas pocas tiendas abiertas y unas pocas están cerradas, aquéllas hacen fiesta y aquéllas hacen su trabajo. Los griegos comen carne cada día de sábado,

sq He aquí una de las motivaciones -si no la única o más importante- del vinje de 'Eliyahu.

6i) Génesis XXXII,9.

ni Es decir, no son católicos romanos, sino ortodoxos, como mís adelante se detalla. 
así como en domingo, y hacen ayuno tres veces al año y se abstienen ellos mismos de toda cosa que sale de ser vivo, ni siquiera comen huevos, ni aceite. Sus curas se casan con una mujer, y si se les muere la primera no toman una segunda; la mayoría de ellos son artesanos. No comen de cosa tocada por los judíos ni por todo el oro del mundo, y no hacen uso de sus utensilios de ninguna manera; si quieres comprarles algún alimento, no lo toques con la mano, sino que debes decir tan sólo: yo quiero esto y eso, pues todo cuanto toques deberás comprar ${ }^{62}$. La carne degollada por judíos es para ellos abominación; ellos odian a los cristianos italianos en gran manera, como nosotros odiamos a los caraítas. Sus mujeres no acostumbran ir de día dando vueltas por la ciudad, y por la noche van a visitar a sus amigas o a la iglesia. Dicen que hacen esto por recato, y por dentro de ellas hay gran adulterio, ¡nueve medidas de depravación tiene el cántaro de barro de la maldad! Todos son hombres mentirosos, tramposos y ladrones, la fe se ha perdido y ha sido extirpada de sus bocas.

Aquí la sal es en extremo hermosa, y dan una medida que pesa dos libras por cinco cuatrinos nuestros. No he visto en todo el mundo un pan tan hermoso como el que he encontrado en este lugar, y es caro; el trigo se vende (a razón) dc una corfa bolonesa por cuatro libras y cuatro sueldos de moneda de Bolonia. El aceite de oliva es muy malo, venden una libra de él de ocho cuatrinos de doce onzas. La mayor parte de la gente usa aceite de sésamo -que es giuggiolena- para freír y cocinar, pues es bueno, y lo venden a dos cuatrinos la onza; pero si lo comes crudo da un gusto como un poco corrompido. Las aceitunas que se comen aquí son gordas como nueces y se venden baratas, como diez cuatrinos una medida que pesa diez libras, y esas aceitunas no se destinan nunca para cocinar, es lo que dice El Mizraht ${ }^{63}$ en el comentario final sobre e] versículo "tierra de aceite, leche y miel", pues hay aceitunas que no hacen aceite. Las granadas se encuentran en gran abundancia, de todas clases, dulces, agrias y agridulces; son muy grandes y tienen el grano grande, bueno a la vista y agradable al gusto, comprarás la más grande por un cuatrino, y las hay que se conservan todo el año, según he oído.

Cuando llegué aquí ya había terminado la época de la vendimia, pues ellos vendimian las uvas en el mes de agosto, y todas las frutas se adelantan en madurar un mes o más de lo que maduran en Italia. También encontré que se habían acabado los melocotones. No he encontrado uva para comer, tan sólo que a veces vienen unos jormaleros de la montaña y traen de ella para vender, negra y blanca, y es buena, no se conserva más que tres o cuatro días. He preguntado por la cuantía del vino y dijeron que este año han vendido una cantidad de una corfa bolonesa por tres libras y catorce sueldos de moneda bolonesa. El vino de aquí es fuerte, se puede mezclar con dos tercios de agua. He comprado la leña a razón de once marcelos de plata una medida, que es como un carro y medio. Las cebollas y los ajos son caros, se venden al doble de los que se

62 Era costumbie entre los cristianos no permitir el contacto físico de sus alimentos por mano judía.

63 Supercomentario at Pentateuco, de 'Eliyah Mizrąíi, erudito nacido en Constantinopla (14501526). Su hijo lsrael se encargó de la edición de esta obra (editio princeps, Venecia 1527). Aquí la referencia es a Deuteronomio XI,9.

Imagen y representación de los otros

Hispania Sacra 48 (1996) 
venden en Italia. La calabaza y los nabos son muy grandes y por cada cuatrino dan una colmadísima carga. Encontrarás toda clase de verduras, como coles, espinacas -spinaci-, carlotas, abrojo, eneldo, menta, mejorana, perejil, ruda, y otras más parecidas, todas en gran abundancia y baratura. Asimismo de toda clase de legumbres, como habichuelas, lentejas, habas -fagioli-, judías blancas (y no rojas), arroz, panizo de todo tipo y cosas así, y no son caras. Todos los días por la mañana y por la tarde encuentras pescado para comprar, y su precio es como en Italia, cuatro de ellos juntos por un dinar, es decir, un cuatrino y medio por unidad. Los gansos y los patos escascan mucho en esta comarca, si encuentras alguno, vale un par de patos cinco o seis marcelos de plata; dos marcelos el par de gansos. Los pollos hermosos, tres marcelos; los medianos, un marcelo y medio el par. Las codornices -es decir, cotornici- un poco menos de un marcelo el par. Las palomas domésticas un marcelo y un poco más el par. Las palomas de palomar, menos de un marcelo. Cinco nueces por un cuatrino, un membrillo por un cuatrino, y son pequeños. Las manzanas escasean y son malas; cuando encuentres de ellas para comprar no te darán más que dos por cuatrino. Todavía no he visto peras, dicen que a veces los jornaleros de las montañas las tracn y las venden caras. En esta región no hay azufaifas -giuggiole-, sorbas ni castañas. Hallarás en gran abundancia citros, limones, naranjas, alcaparras, pistachos, dátiles, algarrobas, higos frescos y secos, y son baratos. El queso que se hace aquí es de leche mezclada de oveja, cabra y vaca, y no se conserva debido a la gran proporción de grasa que tiene; la mayoría de los judíos que hay aquí acostumbran traerlo de Zante y de Trípoli, y es caro.

La víspera de la fiesta de los Tabernáculos fuimos al interior de la ciudad, a los jardines, a comprar palmas y citros, y me escogí dos palmas y dos $\operatorname{citros}^{54}$ grandes y hermosos en extremo; no he visto como ellos en Italia en toda mi vida, y por todo pagué un marcelo dos cuatrinos. El chantre de la sinagoga trajo a mi casa mirto y laurel sin gasto. Los corderos y las cabras son allí, según he oído, hermosos, buenos y baratos, su precio es como un mocenigo y un poco más por unidad, todo según su tamaño, y quien quiera de ellos, debe comprar un cordero (entero), o dos mitades cuentan por un cordero (entero), pues no se encuentra cristianos para venderles los cuartos traseros $^{65}$, pero todavía no han empezado (a venir). Dicen que a finales de este mes empezarán a venir, y ahora los judíos comen carne de vaca o carne de oveja o de cabra, y calculé sus precios en seis o siete cuatrinos la libra. La carne de toro a nueve cuatrinos la libra. La verdad es que extreman la responsabilidad en los que se refiere a las carnes no aptas ${ }^{66}$. En Constantinopla, en Salónica, en Candía y aquí en Chipre, los eruditos han introducido la práctica de soplar para la inspección de los pulmones, pues se com-

64 Plantas empleadas en la celebración de la fieștn de las Cabañuelas o Tabernáculos. Levítico XXIIJ,40.

"s Las leyes rabínicas proscriben el consumo de los cuartos traseros en su integridad, pues hay que extraer cuidadosamente los tendones isquiáticos.

66 Recuérdense los escrúpulos de nuestro viajero en lo referente a la carne no apta entre los judíos de Zante.

Imagen y representación de los otros

Hispania Sacra 48 (1996) 
padecieron del dinero de los israclitas, pues todo cuanto se degüella se llama "reses de Israel" 67 .

La miel aquí es negra y espesa y se vende a razón de dos cuatrinos la libra.

Es bueno para quien posee la sabiduría de la medicina, pues los cristianos y los griegos tienen fe en la sabiduría del judío ${ }^{68}$. La verdad es que el salario que dan, -que es de doscientos cequíes- no lo dan más que al incircunciso, y tambiên hay otro salario que dan los los guardianes a un médico, es decir, una gazeta de Venecia por cada nuevo cautivo, que es como ciento veinte cuatrinos al año; esas dos pagas dan a dos médi$\cos$, pero se encuentran aquí dos judíos médicos. Uno es portugués y otro romano, que ganan mucho y se mantienen mediante la práctica de la medicina; son respetados a los ojos de las gentes y van tocados con el sombrero negro con una pieza verde grande como un isar, cosa que no se permite a los demás judíos, sino que debe ser todo verde como en Venecia.

El gasto por hacer bucati69 es muy grande, y quieren el doble de lo que nosotros acos-tumbramos pagar en Italia. Los calzados son baratos. Te comprarás zapatos grandes y buenos con suela gruesa y págarás un marcelo y medio.

Estos son los límites de (mi descripción de) las costumbres de esta ciudad. A través de mis palabras podréis calcular casi todo lo que es necesario. Viendo que también me he extendido mucho de manera insoportable y que asimismo tengo que escribir a diversos lugares y a otras personas, eligiré por abreviar. En especial porque no podré escribir nada relacionado con el negocio de la mercadería, pues todavía no he visto la costumbre de la región ni lo que es bueno. Exactamente estas palabras escribí a mi hermano -le guarde su Roca y su Refugio- en Pésaro y al altísimo mi suegro -le guarde su Roca y su Refugio- en Ferrara, si tuviese a bien escribirme para hacer bien a mi corazón con la paz de todos los miembros de vuestra casa, uno por uno, haríais lo bueno y justo para conmigo. Pues ciertamente a partir de hoy aguardaré vuestra respuesta para saber cómo estáis; asimismo desearía oír si hay cambios en vuestro país, pues mis ojos y mi corazón están altí todos los días. Tampoco por la noche no se reposa mi corazón de pensar pensamientos acerca de todo cuanto dejé, y en visión nocturna, así como en mis sueños, siempre contemplaré a los pies de vuestros lechos, adormilado y en vela, despierto y llorando, pues estoy solo y pobre en estas regiones, y ninguno de vosotros me fortalece, ¿cuándo vendrá (el momento) que podré ver vuestros rostros excelsos en la Tierra Santa? jOh, Eterno, trae de nuevo a los cautivos como a los cursos de agua a sus secos cauces! ${ }^{70}$ Entonces se colmará nuestro júbilo y será fiesta para los hijos de nuestra familia, en vez de las infinitas lágrimas que vertieron nuestros ojos...

67 Tras el degijello ritual y desangramiento de la res sigue una inspección ocular de las vísceras del animal -bediqah-y es práctica habitual soplar a través de la tráquea para comprobar la elasticidad de los pulmones y membranas pleurales.

68 Otra curios y acertada observación acerca de ta práctica médica entre los judios chipriotas. Vide la nota 22.

69 La colada, en catalín bugada. Vide MAGDALENA NOM DE DÉU, JosÉ RAMÓN: Notas i remarkas sobre la "leshiya" i la "bogada". "AKI YerushaLAYIM" (Jerușalén) 36-37 (1988), p. 50.

70 Salmos CXXVI,4.

Jmagen y representación de los otros

Hispania Sacra 48 (1996) 
Si deseáis escribirme sed diligentes en enviar la epístola en Venecia, de modo que sean llevadas a manos del sabio excelente señor rabino 'Eli 'ézer 'Aškenazí -le guarde su Roca y su Refugio-, sobre el que os he escrito, pues se demorará un mes en Venecia, o un poco más. Asimismo en cada momento que deseéis escribir y tengáis en Venecia a alguien que quiera hacer el servicio, siempre, cada mes, zarpan naves que vienen desde Venecia hasta aquí. Asimismo a Venecia, pues en cuanto vea vuestras epístolas me comprometo con solemne juramento que yo haré otro tanto y escribiré cada vez que se encuentre aquí un viajero. La verdad es que las naves van a Limasol, que está a un trayecto de tres millas lejos de aquí por mar y como a dos millas por tierra, pero cuando las naves llegan allá en el mismo día nosotros sabemos aquí que llegan, pues siempre hay quien va y viene de allí a acá.

Desde la lejant́a me prosternaré ante el ilustrado honorable nuestro maestro $\mathrm{R}$. Menahem Lasa -le guarde su Roca y su Refugio-, maestro para provecho de vuestra esplénida casa; no he tenido noticia acerca de si su nieto Zacarías -le guarde su Roca y su Refugio- todavía está sirviéndoos, como esperaba. Si no, decidle que me escriba también él, y recibirá mi bendición. Con esto saldré de ante vuestra espléndida morada con reverencia, con genuflexión y con prosternación y diré, pues, ipaz!.

Famagusta, día lunes 18 de octubre de (5.)324, primero del mes de Marhešwán. Escrito del joven que limpia el polvo de vuestros pies, el humilde 'Eliyahu da Pesaro -le guarde su Roca y su Refugio- escribe con prisa y dice ipaz!. 


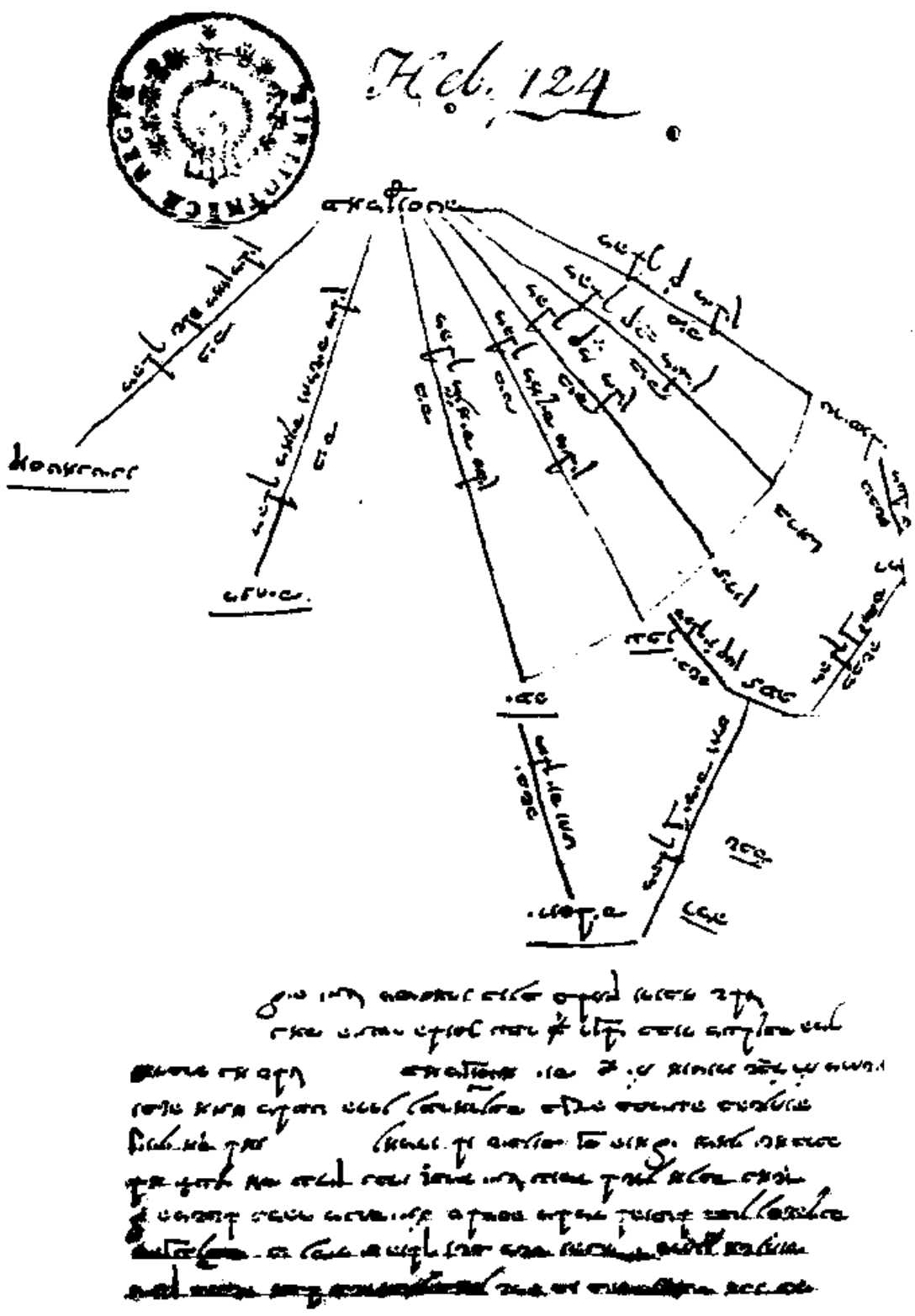

Esquema de los trayectos entre Famagusta y diversos puertos mediterráneos de Levante. Se indican asimismo los caminos terrestres más importantes. p. $123 \mathrm{v} .^{\circ}$ del ms. hebraico.

Imagen y representacion de los otros

Hispania Sacra 48 (1996) 


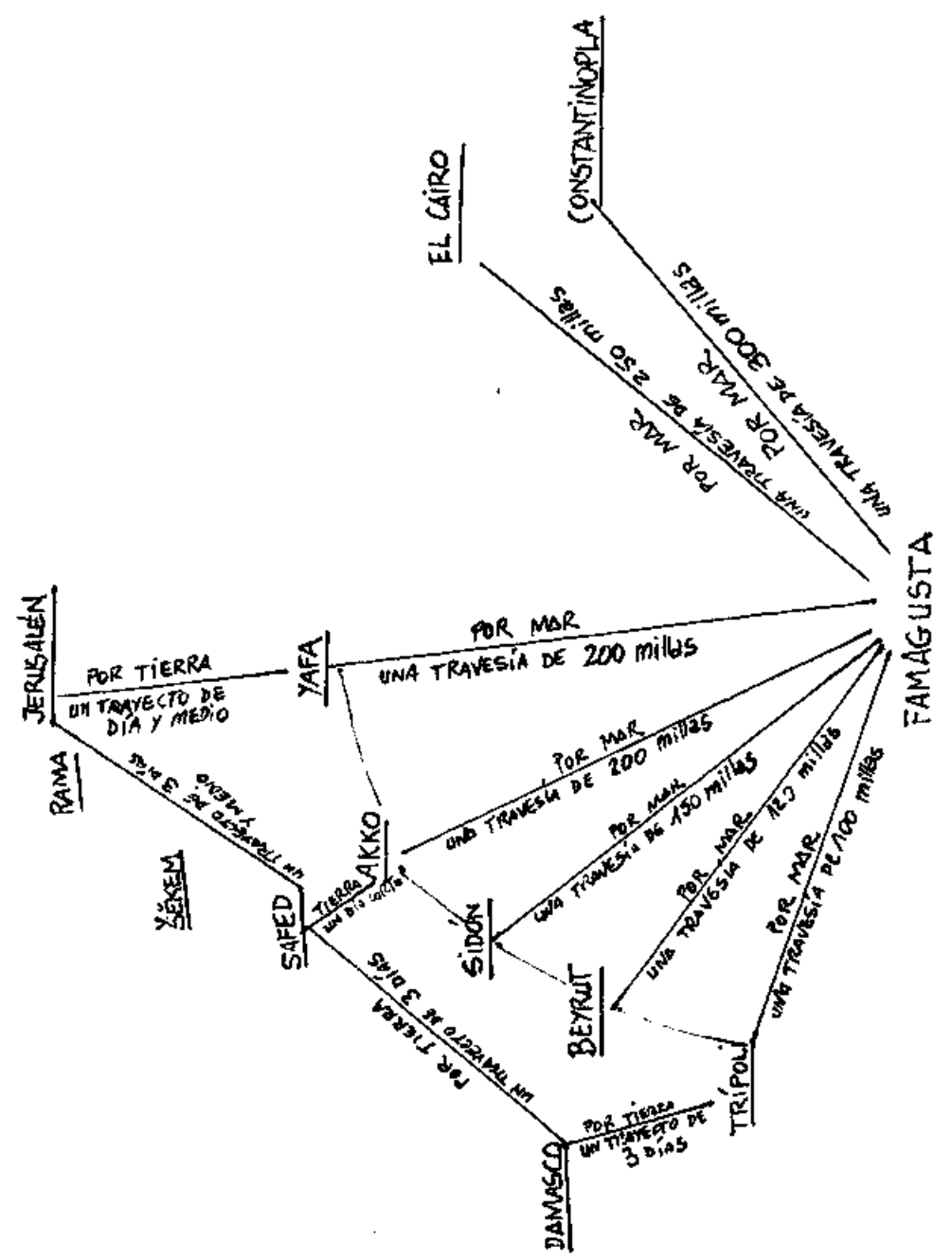

lanagen y representación de los otros Hispania Sacra 48 (1996) 


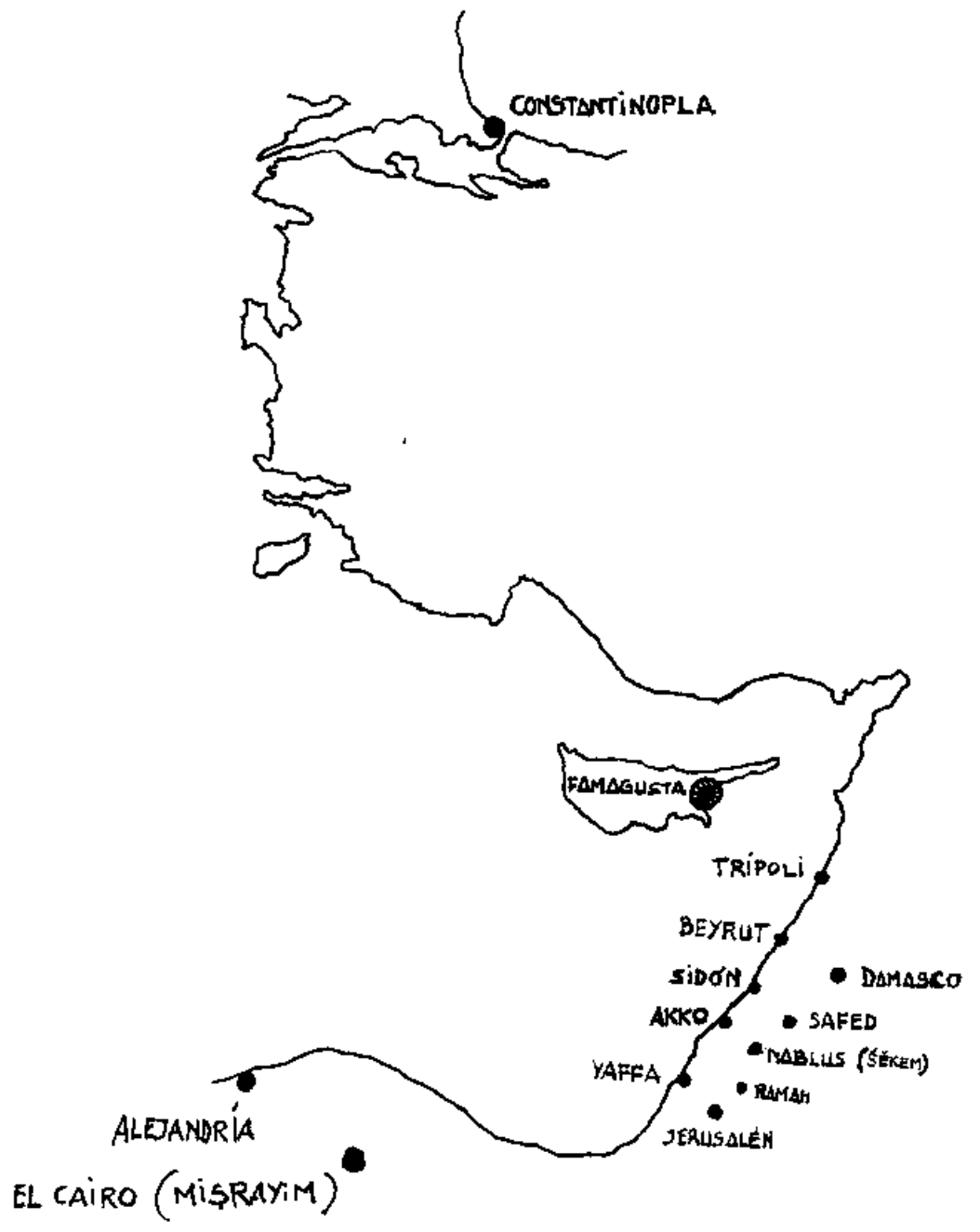

Imagen y representación de los atros

Hispania Sacra 48 (1996) 